\title{
The design of thermal tunnel energy segments for Crossraill, UK
}

1 Duncan P. Nicholson MSc, DIC, CEng, MICE Director, Ove Arup and Partners Ltd, London, UK

2. Qing Chen MSc, FGS Senior hydrogeologist, Ove Arup and Partners Ltd, London, UK

3 Mike de Silva BSC, PhD, FCIWEM, MIEEM, CSCi Sustainability Manager, Crossrail Ltd, London, UK
$4 \quad$ Alan Winter BSC, CEng, MICE Bored Tunnel Engineer, Crossrail Ltd, London, UK

5 Ralf Winterling MSc, Dipl.-Ing. Technical Manager, Rehau A G+Co, Germany
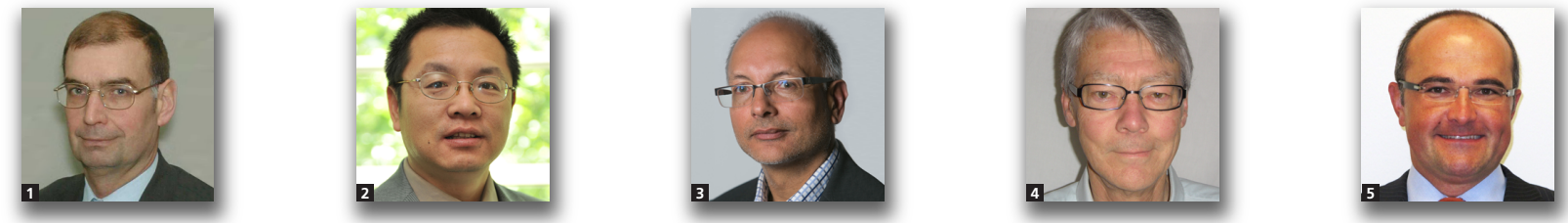

Significant heat is generated by underground trains, particularly when braking, stopping at platforms and accelerating away from stations. A complex ventilation system including shaft, fans and under-platform extraction thus has to be designed to manage the rising temperature in tunnels and stations. This conventional approach results in high energy consumption for running the fans and neglects the possibility to use the extracted heat above ground in buildings. Lining underground rail tunnels with heat-exchange segments can provide an alternative solution to cool the tunnels and surrounding ground, and transfer the harvested heat to adjacent buildings for heating. It will also bring benefits in terms of reduction of energy consumption for tunnel ventilation operations. This paper reports on the work carried out in designing thermal energy segments for use on the tunnelled sections of the Crossrail project in London, UK.

\section{Introduction}

Shallow ground has a large potential of low enthalpy energy that can be used to meet buildings' heating and cooling demands. With the advances in ground source heat pump technology, it is becoming increasingly feasible to capitalise on this geothermal energy present in the ground. The biggest advantage of the geothermal energy is that the soil temperature reaches a constant at a depth of approximately $10-15 \mathrm{~m}$ below surface. For example, in central London, UK, the soil temperature at $14 \mathrm{~m}$ below the surface remains undisturbed at around $14^{\circ} \mathrm{C}$. Outside London, the soil temperature is slightly lower.

Recent development has seen the use of foundation piles, diaphragm walls and base slabs as ground heat exchangers (Adam and Markiewicz, 2009; Brandl, 2006; Fry, 2009). For example, thermal piles and walls involve attaching polymer absorber pipes to the reinforcement cages and this approach has been applied to Crossrail stations. Other application examples involving sprayed concrete linings include the tunnels at Stuttgart Metro U6 (Schneider and Moormann, 2010),
Lainzer Tunnel (Adam and Markiewicz, 2009) and the metro stations (Brandl et al., 2010). Heat-exchange pipes have been placed along the lengths of the Channel Tunnel to extract heat from inside the tunnel (personal communications).

The paper by Franzius and Pralle (2011) discusses embedding plastic absorber pipes in the precast concrete tunnel segments of a conventional metro to collect heat from the adjacent ground. However, at Crossrail the primary heat source is the waste heat rejected from trains, and the surrounding ground is the secondary source. The harvested heat is transferred by way of header pipes to the ground surface, and connected to heat pumps to supply the heating energy to buildings. Figure 1 shows the conceptual design of the tunnel energy segment (TES) system.

\section{Assessment of the heat inside the tunnel}

Operation of the London Underground network over the past 100 years has gradually warmed the surrounding geology of London Clay. In the early 1990s, the tunnels' temperature was constant at around $15^{\circ} \mathrm{C}$. Over the century, the ground around the tunnel has become unable to absorb the waste heat from 
Engineering Sustainability

Volume 167 Issue ES3
The design of thermal tunnel energy segments for Crossrail, UK

Nicholson, Chen, de Silva, Winter and Winterling

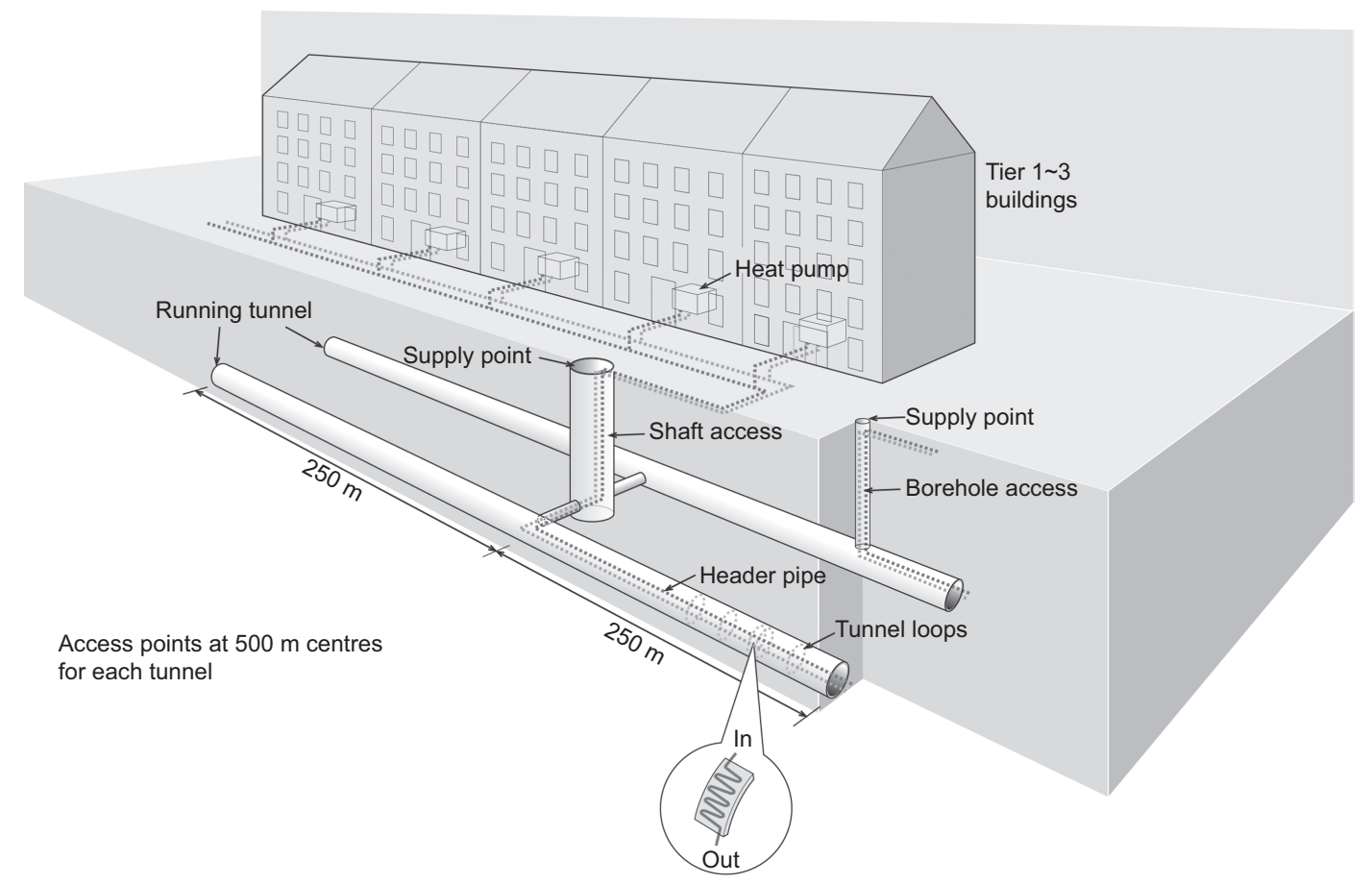

Figure 1. Schematic diagram of the tunnel energy segment system

trains effectively. The consequence is that today's temperature in many underground lines remains high throughout the year, with temperatures of more than $30^{\circ} \mathrm{C}$ in some parts of the network (Botelle et al., 2010). High air temperature presents a big challenge to the underground train operators. In future, climate change will likely exacerbate the current situation, with the mean temperatures projected to increase by $2-6^{\circ} \mathrm{C}$ higher than normal within the next 40 years (Defra, 2011, 2012).

To start with, an assessment of the available heat energy inside tunnels was carried out. Train heat is emitted from the motors, air conditioning systems and brakes. This waste heat is injected inside the tunnel, which warms the air and surrounding soil mass.

It is the intention that Crossrail will be a 118 railway line serving London, the central part of which is a twin tunnel underneath London from Paddington to Stratford, and a branch line will run from Whitechapel to Abbey Wood. The length of tunnel is about $21 \mathrm{~km}$ long, for a twin tunnel, the total length is $42 \mathrm{~km}(2 \times 21 \mathrm{~km})$. As seen in Table 1, at peak time there are 24 trains each hour in each direction, meaning one train per $2.5 \mathrm{~min}$. Assuming the average train speed is $60 \mathrm{~km} / \mathrm{h}$, a train will take $21 \mathrm{~min}$ to complete the journey. Hence, the number of trains inside the tunnel at any one time during peak hours is $21 / 2 \cdot 5=8 \cdot 4$ trains.
Assuming one train motor generates on average $1 \mathrm{MW}$ net heat, and its air-conditioning unit generates about $0 \cdot 1 \mathrm{MW}$, the total heat output rate from 8.4 trains is $1 \cdot 1 \times 8 \cdot 4=9 \cdot 2 \mathrm{MW}$. The tunnel internal diameter is $6 \cdot 2 \mathrm{~m}$, the total surface area of the tunnel wall will be about $410000 \mathrm{~m}^{2}$. Therefore, the peak heat output rate in terms of tunnel lining area is $9 \cdot 2 \times 10^{6} \%$ $410000=22 \mathrm{~W} / \mathrm{m}^{2}$ of tunnel surface area. On a weekly basis, the average number of trains is 14 trains per hour. The average heat output is thus $22 \times 14 / 24=13 \mathrm{~W} / \mathrm{m}^{2}$. In addition, the surrounding strata behind the tunnel linings would also serve as a heat source similar to the ground mass of a closed-loop ground-source heat pump design. The train's heat emission also increases dramatically during braking when the train approaches the platform and accelerates away from the station. Therefore these sections have higher heat output and are the locations where TES should be focused. For comparison, the typical heat exchange rate for closed-loop boreholes is $35 \mathrm{~W}$ per metre of borehole depth and about $60 \mathrm{~W}$ per metre run for small diameter geothermal piles (Brandl, 2006).

Based on the above simplified calculation, the base heat output from the train operation is about $7 \mathrm{~W} / \mathrm{m}^{2}$ base and the peak output is about $30 \mathrm{~W} / \mathrm{m}^{2}$ peak. On this basis a $500 \mathrm{~m}$ length of tunnels would be able to support about 100 family apartments with a total heat demand of $1200 \mathrm{MWh} /$ annum, which would be met by a combination of a $400 \mathrm{~kW}$ gas boiler and a $400 \mathrm{~kW}$ 


\begin{tabular}{|c|c|c|c|c|}
\hline From & To & Hours & Train frequency & No. of trains \\
\hline \multicolumn{5}{|c|}{ Monday-Friday } \\
\hline 00:00 & $00: 30$ & $0 \cdot 50$ & 12 & 6 \\
\hline $00: 30$ & $05: 45$ & $5 \cdot 25$ & 0 & 0 \\
\hline 05:45 & $06: 15$ & 0.50 & 12 & 6 \\
\hline $06: 15$ & 07:00 & 0.75 & 16 & 12 \\
\hline 07:00 & $07: 45$ & 0.75 & 20 & 15 \\
\hline 07:45 & 09:15 & $1 \cdot 50$ & 24 & 36 \\
\hline 09:15 & $10: 00$ & 0.75 & 20 & 15 \\
\hline 10:00 & $16: 00$ & $6 \cdot 00$ & 18 & 108 \\
\hline $16: 00$ & $16: 45$ & 0.75 & 20 & 15 \\
\hline $16: 45$ & $18: 15$ & $1 \cdot 50$ & 24 & 36 \\
\hline $18: 15$ & 19:00 & 0.75 & 20 & 15 \\
\hline 19:00 & $22: 00$ & $3 \cdot 00$ & 16 & 48 \\
\hline \multirow[t]{2}{*}{$22: 00$} & 00:00 & $2 \cdot 00$ & 12 & 24 \\
\hline & & & Total no. & 336 \\
\hline \multicolumn{5}{|c|}{ Saturday } \\
\hline 00:00 & $00: 30$ & 0.50 & 12 & 6 \\
\hline $00: 30$ & 05:45 & $5 \cdot 25$ & 0 & 0 \\
\hline 05:45 & 09:00 & $3 \cdot 25$ & 12 & 39 \\
\hline 09:00 & 21:00 & $12 \cdot 00$ & 18 & 216 \\
\hline \multirow[t]{2}{*}{ 21:00 } & 00:00 & $3 \cdot 00$ & 12 & 36 \\
\hline & & & Total no. & 297 \\
\hline \multicolumn{5}{|l|}{ Sunday } \\
\hline 00:00 & 07:00 & $7 \cdot 00$ & 0 & 0 \\
\hline 07:00 & $12: 00$ & $5 \cdot 00$ & 12 & 60 \\
\hline $12: 00$ & 21:00 & $9 \cdot 00$ & 18 & 162 \\
\hline 21:00 & $23: 45$ & $2 \cdot 75$ & 12 & 33 \\
\hline \multirow[t]{2}{*}{$23: 45$} & 00:00 & 0.25 & 0 & 0 \\
\hline & & & Total no. & 255 \\
\hline
\end{tabular}

Table 1. Crossrail designed train frequency during normal operation (SP2)

heat pump. The full network of Crossrail tunnels comprise 84 such lengths and would consequently have the capacity to provide heat for 8400 families (30 000 people) or equivalent building heating.

\section{Design of the TES system}

\subsection{Previous experience}

There are a number of existing case studies on retrieving heat energy from tunnels. The Vienna LT22 testing plant was the first geothermally activated sprayed concrete lining tunnel in Austria. The absorber pipes were attached to a geosynthetic and placed between the primary and secondary tunnel lining (Adam and Markiewicz, 2009). A similar installation was built at Stuttgart Metro U6 in Germany (Schneider and Moormann, 2010). More recently, thermal structures have been built in TBM Tunnels. Züblin AG and Rehau AG \& Co have championed this development with a field test in the Katzenberg high-speed rail tunnel in Germany followed by the Jenbach twin track highspeed rail tunnel in Austria, which incorporated a $54 \mathrm{~m}$ long demonstration section with thermally activated segmental tunnel lining equipped with heat exchange pipes (Franzius and Pralle, 2011). These cross-linked polyethylene (PE-Xa) pipes were connected to a heat pump in the utility centre building to provide hot water and space heating. It should be noted that all the above schemes are taking heat from the ground mass behind the tunnel linings rather than the tunnel air.

\subsection{Crossrail experience}

From the start, the Crossrail TES design team have been facing demanding technical and management challenges.

First, the TES design only started after the tunnel design had been completed and tendered. Therefore the TES design needed to cater for the heat exchange pipe 
Engineering Sustainability

Volume 167 Issue ES3
The design of thermal tunnel energy segments for Crossrail, UK

Nicholson, Chen, de Silva, Winter and Winterling requirements, while still meeting the existing design requirements for structural, fire, heat and ventilation $(H \& V)$ and so on. For example, a design method had to be developed to enable the existing tunnel $\mathrm{H} \& \mathrm{~V}$ design to be revised to incorporate the TES. Another example, the introduction of box-out pockets at the ends of the segments to form pipe connection needed to take account of the caulking groove featured in the segment structural design.

- Second, incorporating the heat exchange pipes in the segment casting and ways of forming tunnel ring connections requires numerous discussions with tunnel contractors and design changes. The aim is to develop methods that the TES would not delay normal tunnel construction or introduce high costs.

- Third, TES needed to identify and manage a network of buildings that could use the heat.

- Fourth, the Crossrail board needed to have design risk assessments and budget costs so that they could make informative decisions.

All these challenges need to be resolved to a demanding time frame. This complex and innovative design would require effective coordination of inputs from a multidisciplinary team, including building services, costing, energy, fire, hydrogeology, geotechnics, material, mechanic and electrical engineering, structures, risk management, tunnelling and ventilation engineering, and so on.

\subsection{Thermal energy segments}

In order to extract heat from the tunnel, the concept design is to embed $20 \mathrm{~mm}$ internal diameter heat-exchange pipes (absorber) in the conventional concrete segments before casting. The segments are fabricated using a standard segmental lining manufacturing process. The absorber pipes are placed into the segment in a meandering fashion to maximise heat abstraction potential. For steel reinforced segments used on the floating track sections, the heat-exchange pipes are either tied to the steel cage or on a separate support mesh. For fibre reinforced segments, the pipes are softened in a hot water bath and then attached to a light cage before being positioned inside the segment moulds. To minimise fire risk and prevent accidental damage in the future, the pipes are placed at least $200 \mathrm{~mm}$ from the intrados. To meet minimum pipe bending radii, $300 \mathrm{~mm}$ pipe spacing has been adopted based on the PE-Xa polymer pipe specification. Figure 2 shows a typical pipe arrangement for a segment tied to a reinforcement cage before concrete is poured.

In order to form the longitudinal connections between segments, box-outs are specially designed at the ends of each segment. These pockets are $200 \mathrm{~mm}$ long, $100 \mathrm{~mm}$ wide and $70 \mathrm{~mm}$ deep to allow a permanent mechanical coupling of the adjacent pipe-ends to be performed. As shown in Figure 3, the

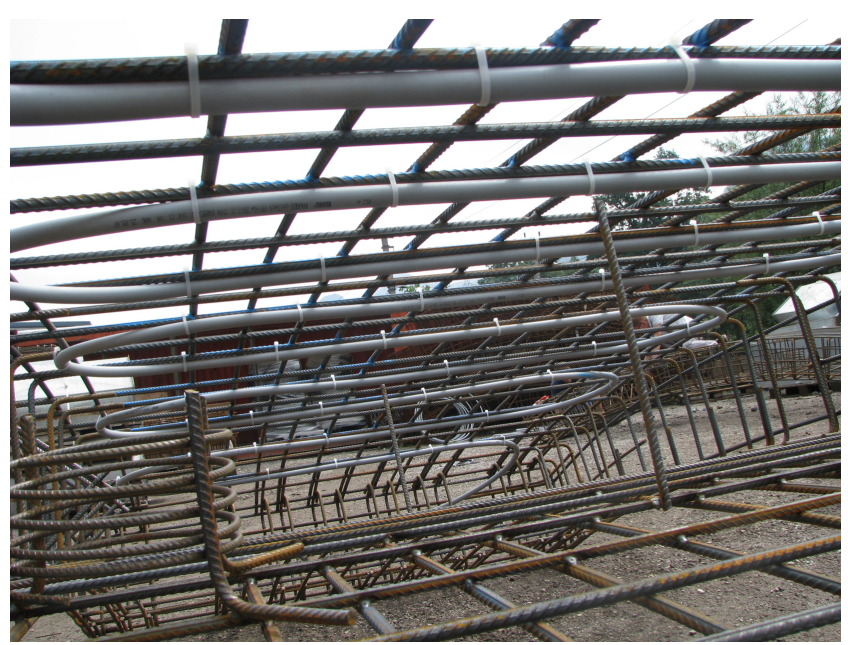

Figure 2. Absorber pipes assembled to a reinforcement segment before casting (photograph taken from Jenbach tunnel by Rehau Ltd) PE-Xa Absorber Pipe attached to reinforcement cage (photo: H8 Tunnel Austria, JV Ed. Züblin AG)

Crossrail box-outs have reverse tapers in order to retain the mortar filler.

The impacts on structural integrity and fire safety introduced by these changes to standard segment design are discussed later.

During installation, the pipe connections are formed immediately after the segment ring is erected at the tunnel face. The majority of work can be carried out from the erection train towed behind the tunnel boring machine (TBM). The connection system was initially developed for thermally activated building structures in high-rise buildings for pipe connections buried in the concrete structure. The system allows permanent mechanical connections (Everloc) to be rapidly made in a small

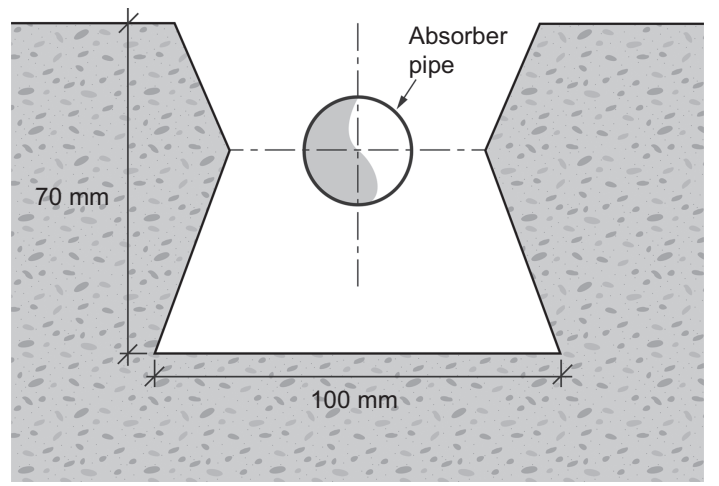

Figure 3. Reversely tapered box-out at the end of segments 


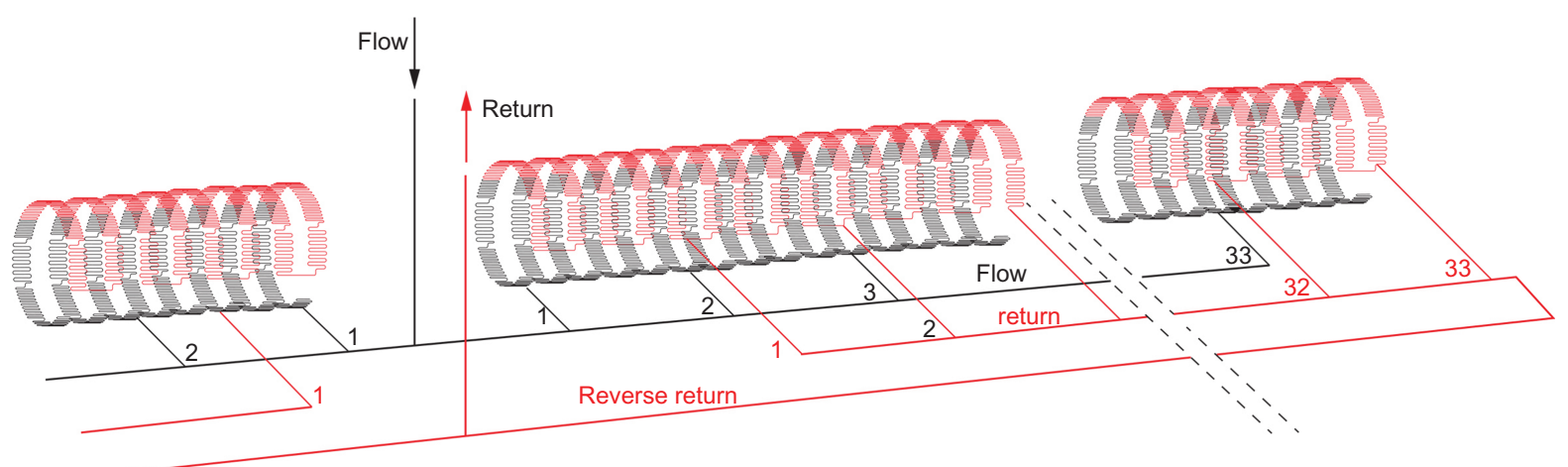

Figure 4. Schematic diagram of pipework connections with three header pipes configuration

space to reduce the installation time. Once formed, these connections cannot be undone. The Everloc permanent couplings have been subjected to pressure tests and the results show that the polymer pipe fails before the joint; this provides confidence in the integrity of the couplings.

To allow a continuous flow within a lining ring, the absorber pipes in the six segments and one keystone of the ring are joined up. Five neighbouring rings are connected longitudinally to form a complete circuitry, see Figure 4. Each circuit is connected to the flow and return header pipes. Control valves are installed to isolate individual circuits in the event of a local failure and to assist with the de-airing process. The ring-to-ring connection positions cannot be predetermined because each ring is slightly tapered; the orientation of the taper is selected during tunnel construction to steer the tunnel as the work progresses. Hence the ring-to-ring pipe connections are formed by variable lengths of plastic polymer pipe mounted on the tunnel surface, see Figure 5.

There are about $11 \mathrm{~m}$ of absorber pipe inside one standard segment. There are seven segments plus one keystone in one complete ring, resulting in approximately $77 \mathrm{~m}$ of pipe per ring. There are five rings in one circuit and 31 circuits would cover about $250 \mathrm{~m}$ tunnel length. Tunnel header pipes would be connected to the surface through shafts and stations. Alternatively, dedicated access boreholes could be provided at preferred surface locations for the header pipes as shown in Figure 1.

It has been planned that heat from the tunnels would be connected to district heating networks supplying heat energy to blocks of buildings along the tunnel alignment. The income from the sale of heat to the district heating energy supply companies will provide a revenue stream to the tunnel operator that finances the installation and operation of the TES.

\subsection{TES system design: pipework hydraulics and plant room}

The three header pipe 'reverse return' arrangement was selected in preference to the two-pipe arrangement because of the advantage of self-balancing, see Figure 4. The return header is connected to the most hydraulically remote point, therefore distributing the flows and pressures more evenly across the system. This makes the reverse return arrangement more inherently balanced compared to the direct return one. A procedure for removing trapped air was developed. Pressure losses were calculated for routine operation, and flushing operations for individual circuits and the header pipes to remove air bubbles.

The flow rate through the circuit varied depending on the heat extraction rate. A flow rate of $0.06 \mathrm{l} / \mathrm{s}$ would achieve $10 \mathrm{~W} / \mathrm{m}^{2}$ heat extraction rate and $0 \cdot 12 \mathrm{l} / \mathrm{s}$ would achieve $30 \mathrm{~W} / \mathrm{m}^{2}$. The pressure losses for all fittings are calculated in accordance with Chartered Institution of Building Services Engineers (CIBSE) Guide C (CIBSE, 2007) except for the long radius U-bends that form the meander of the pipes within the segments. The calculations for normal operations included a $50 \mathrm{kPa}$ pressure drop for fittings on the circulation pump, and an additional $100 \mathrm{kPa}$ pressure drop for the heat exchanger. During the air bubble flushing operation, the heat exchanger would be bypassed, so only $50 \mathrm{kPa}$ pressure drop has been included in the calculations. The system is balanced using a reverse return arrangement with valves on each circuit and an additional valve at the connections between the flow and return pipes. A schematic diagram of the assumed layout is shown in Figure 5. A design margin of $15 \%$ is applied on the calculated pressure drop across the pipe network. The flow in the circuits needs to maintain a turbulent state to ensure efficient heat exchange.

For normal operation header pipe lengths of $250 \mathrm{~m}$ were planned. Increasing the length to $500 \mathrm{~m}$ would result in the 


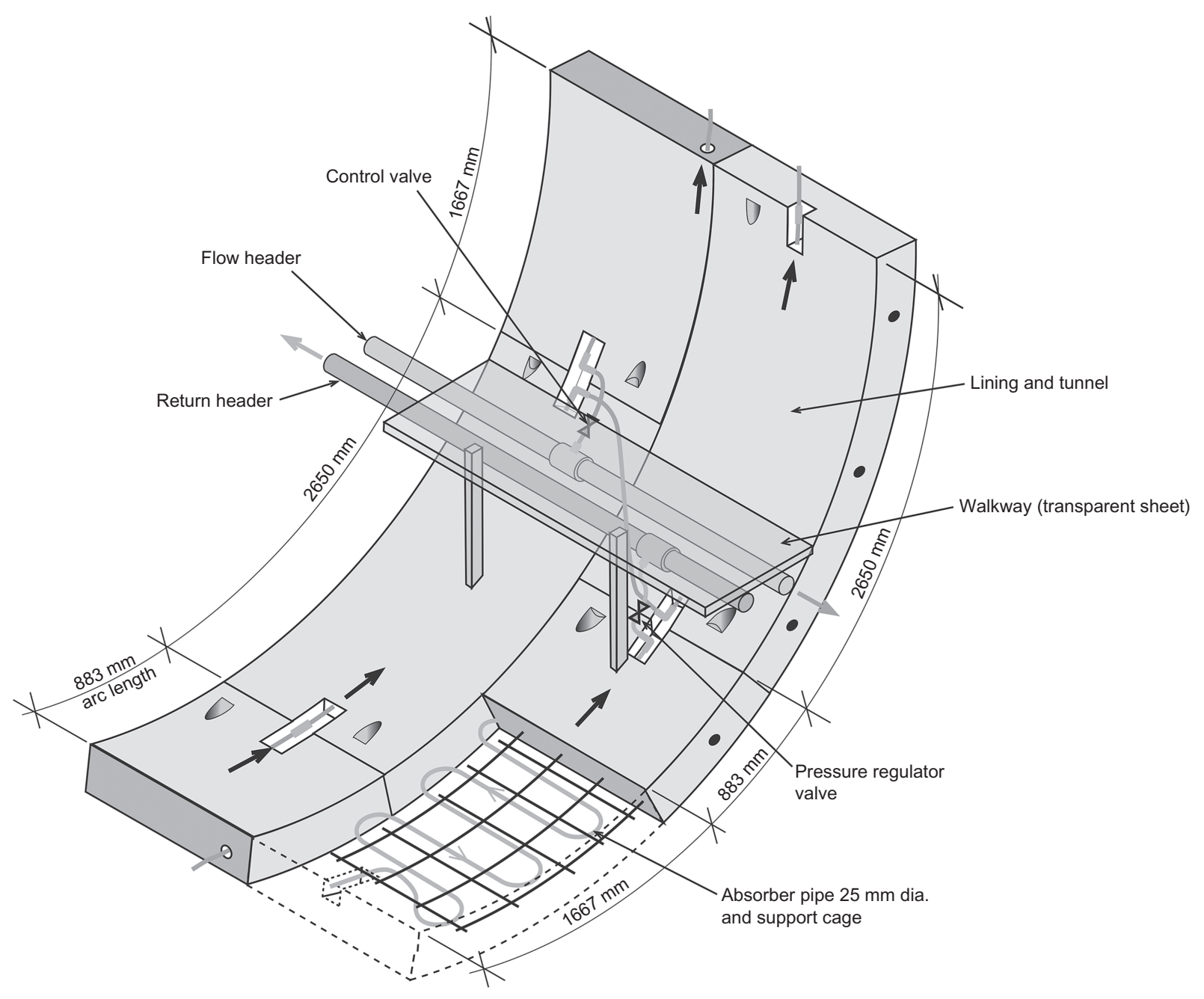

Figure 5. Schematic diagram of TES design

system's maximum pressure loss rising from $7 \cdot 5$ bar to $9 \cdot 1$ bar, assuming the header pipes are of $90 \mathrm{~mm}$ internal diameter.

To ensure the smooth running of the TES system, it needs to be flushed and purged regularly to remove any trapped air from the circuits. This could be done in two steps: first, the ring circuit will be flushed individually. This procedure involves closing all the valves except the one leading to the target circuit. Based on the recommendations of MIS 3005 standard (MIS, 2013), the minimum flow rate of $1.0 \mathrm{~m} / \mathrm{s}$ in the loops is assumed; second, air is to be removed from the system flushed by the header pipe by closing all the circuit valves. The maximum pressure head loss is expected to reach 8.3 bar for a $250 \mathrm{~m}$ long section, and $12 \cdot 6$ bar for a $500 \mathrm{~m}$ section.

To ensure the hydraulic performance could be maintained, it is recommended that the header pipe length is between $250 \mathrm{~m}$ and $400 \mathrm{~m}$ on each side of an access point (e.g. ventilation shafts or boreholes). Increasing the header pipe length leads to a significant increase in pressure loss during operations, and greater risks of pipe and joint integrity.

\section{Potential market for the tunnel heat}

The London heat map and its building inventory along the Crossrail alignment were used to identify buildings adjacent to the tunnel alignment that could use the heat from the TES. These buildings were mapped on geographic information system (GIS). Two selection criteria were considered. First, the buildings should have a sufficiently large heat demand to justify connection to the system. The minimum threshold of heat demand was based on the available heat from the tunnel, which is classified by annual heat demand of $600 \mathrm{MWh}$, $1200 \mathrm{MWh}, 1800 \mathrm{MWh}$ and $2400 \mathrm{MWh}$. Second, by building type: the buildings should have a heat load profile that 
The design of thermal tunnel energy segments for Crossrail, UK

Nicholson, Chen, de Silva, Winter and Winterling

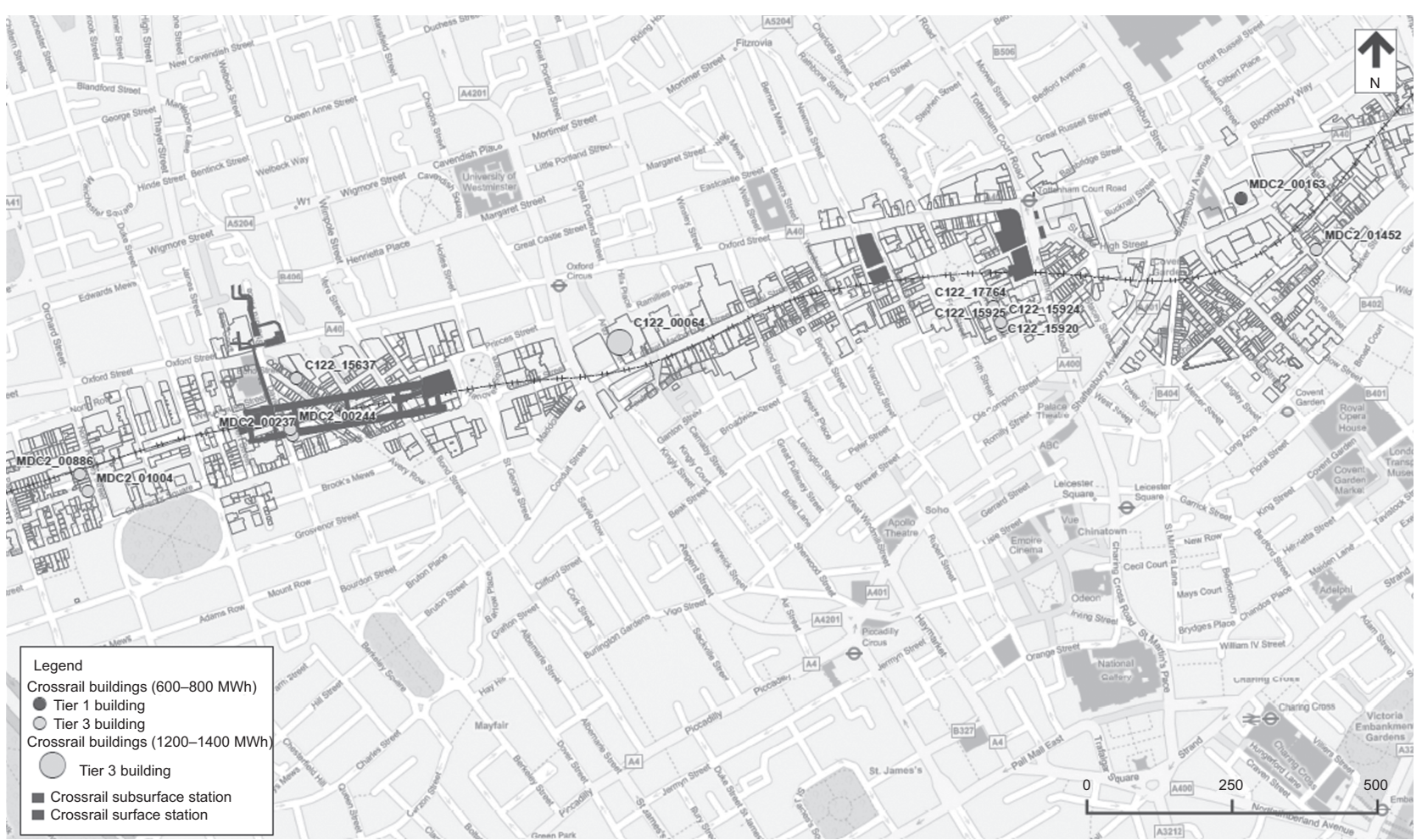

Figure 6. GIS study of existing energy users along the route. Tier 1 buildings at three locations - Canary Wharf, Bond Street and Liverpool Street - are shown

complements the efficient heat pump operation; that is, relatively constant heating base load. These two criteria were used to divide the buildings into three tiers: tier 1 - most suitable buildings, tier 2 - moderate suitability and tier 3 - low suitability buildings.

The types of buildings are

- tier 1: hotels, large residential buildings, hospitals

- tier 2: schools, higher education, public libraries, museums

tier 3: offices, leisure centres, retails.

As a result of this investigation, 365 buildings with a heat load greater than $600 \mathrm{MWh} / a n n u m$ were identified within $100 \mathrm{~m}$ of the Crossrail tunnel alignment. These buildings comprised 34 tier 1, four tier 2 and 327 tier 3 buildings. Some of these are shown in Figure 6.

The technically feasible surface connection points based on ventilation shafts and tunnel access routes are shown in Figure 7. Circles of $250 \mathrm{~m}$ diameter centred at the access points are shown for the standard connection header pipe length. At some locations it may be necessary to increase the capacity of the header pipes where the circles did not intersect. This would enable the TES connections to the majority of the suitable buildings along the tunnel route.

\section{Modelling of TES heat transfer}

A two-dimensional finite-element (FE) thermal model was developed using numerical code LS-Dyna to simulate the thermal transfer behaviour of the TES, see Figure 8. LS-Dyna is a multi-physics simulation software package; the model developed here is a coupled thermal-mechanical model. As the tunnel is radially symmetrical, only a wedge through the tunnel lining and the soil behind is modelled. Within the concrete liner, the absorber pipes are buried at $200 \mathrm{~mm}$ depth and spaced at $300 \mathrm{~mm}$. Heat transfer by conduction is modelled between the fluid inside the pipes and the concrete, the concrete and the soil, and the concrete and the tunnel air. In practice, the fluid inside the pipe will be cooler near the inlet and warmer near the outlet. For simplicity, the fluid temperature in the model is represented by an average temperature along the length of the pipe.

The thermal properties of the soil and concrete used in the model are summarised in Table 2. The heat transfer coefficient 


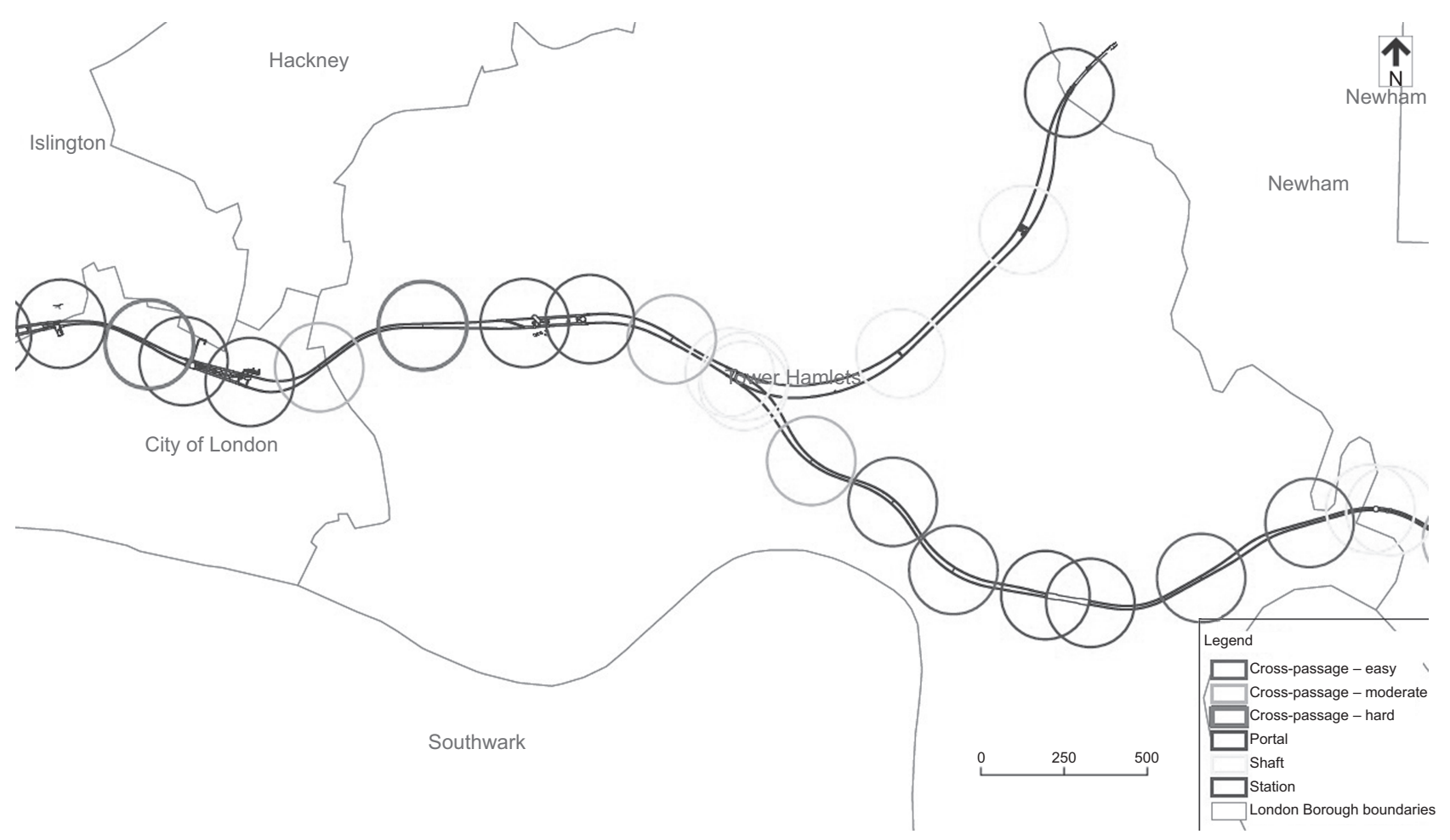

Figure 7. Analysis of surface connections. Each circle is of $250 \mathrm{~m}$ radius. Surface connection options are considered for shafts, crosspassages and directional drilled boreholes

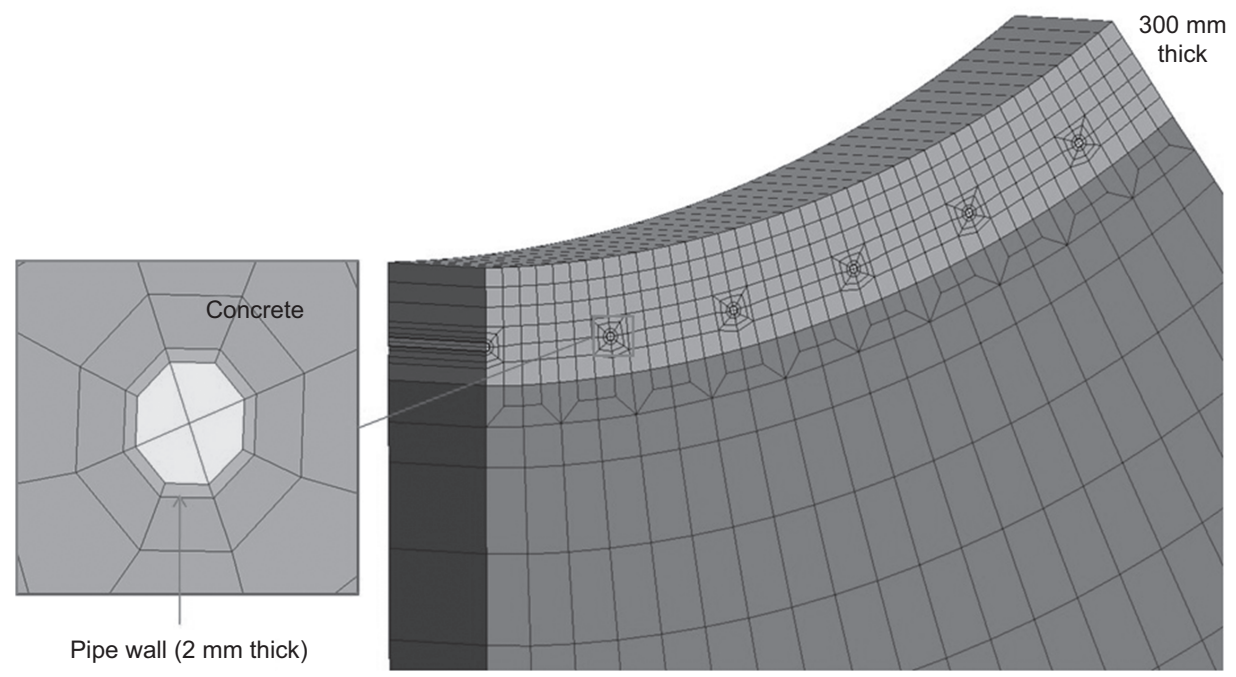

Figure 8. Set-up of the numerical thermal model in LS-Dyna to simulate heat transfer to absorber pipes 


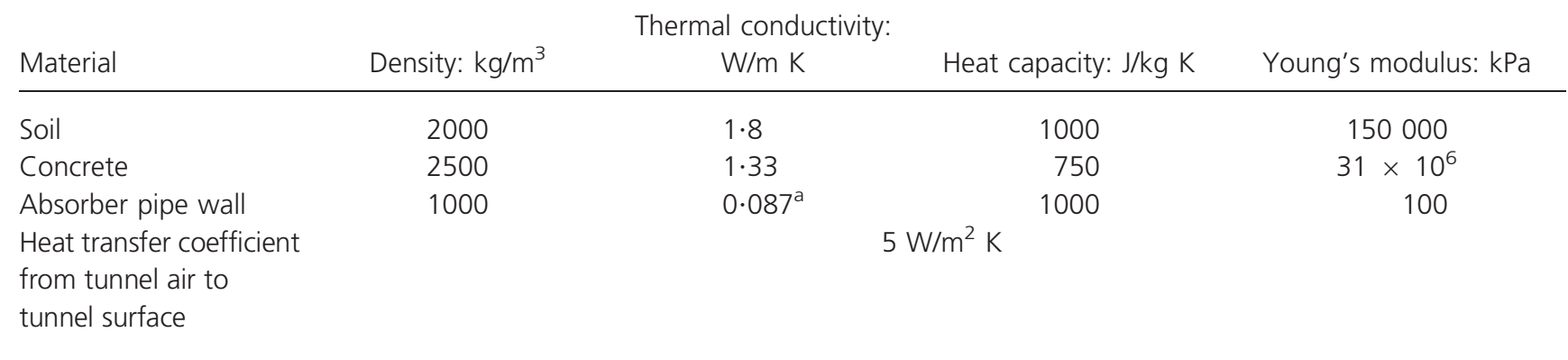

apipe wall conductivity was determined in a validation study for cooled floors, it includes thermal resistance for convective transfer into the fluid inside the pipe as well as conduction through the pipe wall.

Table 2. Thermal parameters used in LS-Dyna thermal analysis

from tunnel air to the concrete wall was assumed to be $5 \mathrm{~W} / \mathrm{m}^{2} \mathrm{~K}$, which was considered a conservative assumption. The tunnel is normally $15-20 \mathrm{~m}$ below ground; the ambient soil temperature at this depth is without seasonal variation. The radial distance of thermal influence by the tunnel on soil mass is limited. In the model, a constant thermal boundary condition of $14.8^{\circ} \mathrm{C}$ was set at a distance of $100 \mathrm{~m}$ from the tunnel. This boundary was based on monitoring in central London. The tunnel air temperature varies seasonally, from $36^{\circ} \mathrm{C}$ in summer to $17^{\circ} \mathrm{C}$ in winter, based on the tunnel ventilation simulations.

During simulation, there was no heat extraction for the first 3 years of simulation in order to establish thermal steady state within the tunnel linings and the soil mass behind it. This was followed by a continuous heat extraction for a further 7 years.

Sensitivity analyses were carried out for heat extraction rates ranging from 5 to $50 \mathrm{~W} / \mathrm{m}^{2}$, where the area refers to tunnel lining surface area. The resulting fluid temperature is presented in Figure 9. This figure shows that the TES system would reach quasi steady state within the first year of operation. The model predicts that during winter the fluid temperature will be $16^{\circ} \mathrm{C}$ for $5 \mathrm{~W} / \mathrm{m}^{2}$ heat extraction rate, and will reduce linearly with the heat extraction rate to $-6^{\circ} \mathrm{C}$ for $50 \mathrm{~W} / \mathrm{m}^{2}$. The soil temperature does not drop below $+3{ }^{\circ} \mathrm{C}$, even at the soil-tunnel interface. In order to avoid freezing, the continuous heat extraction rate of the absorber pipes must be no more than $30 \mathrm{~W} / \mathrm{m}^{2}$ in winter.

At heat extraction rates between 5 and $20 \mathrm{~W} / \mathrm{m}^{2}$, the outlet fluid temperature from the TES is relatively high (above $8^{\circ} \mathrm{C}$ in winter). This will enable the TES system to operate at high coefficient of performance (COP).

\section{Tunnel cooling study}

Heat produced inside the tunnel is traditionally either dissipated through the tunnel walls into the ground or discharged to the atmosphere through air movement. The latter can be achieved by means of draft relief, ventilation shafts, under-platform extract and over-track extract. An aerodynamic model is developed to take into account the geometry of the underground system of tunnels, the train movements and the main mechanism of air movement. The aerodynamic predictions are then used as a periodic forcing function in the thermodynamic model to calculate air, tunnel lining and ground temperatures, air humidity, and heat loads from trains over years. The coupled model has been used for the design of ventilation systems for Crossrail.

To understand the cooling effect of the TES inside the tunnel, the thermodynamic model described above was modified to include the TES pipework, see Figure 10. The heat transfer between the air, the tunnel wall and the ground is simulated using a one-dimensional heat transfer model, which divides the tunnel linings and the ground into concentric rings in each element. The model predicts the air temperature, the tunnel wall temperature and the inlet/outlet temperature of the TES circuit for various heat extraction rates. Heat transfer between air and the flow/return headers is considered insignificant and can be ignored. For details of the numerical study on TES cooling efficiency, see Biotto et al. (2013). The new model was validated by comparing the results with the LS-Dyna numerical model.

Thermal simulations were carried out for the design full-load train service pattern SP2 (240 m long trains, 24 trains per hour service frequency during peak hours), with TES operating at a continuous predefined heat extraction rate.

The ventilation model predicts a reduction in peak tunnel air temperatures of $2-4^{\circ} \mathrm{C}$ (dry bulb (DB)) with the pipework installed along the entire length of the running tunnels and a continuous heat extraction rate of $10 \mathrm{~W} / \mathrm{m}^{2}$, see Figure 11 . The air temperature reduces by approximately $2^{\circ} \mathrm{C} \mathrm{DB}$ at stations, and $2-4^{\circ} \mathrm{C} \mathrm{DB}$ in the running tunnels. Greater temperature 


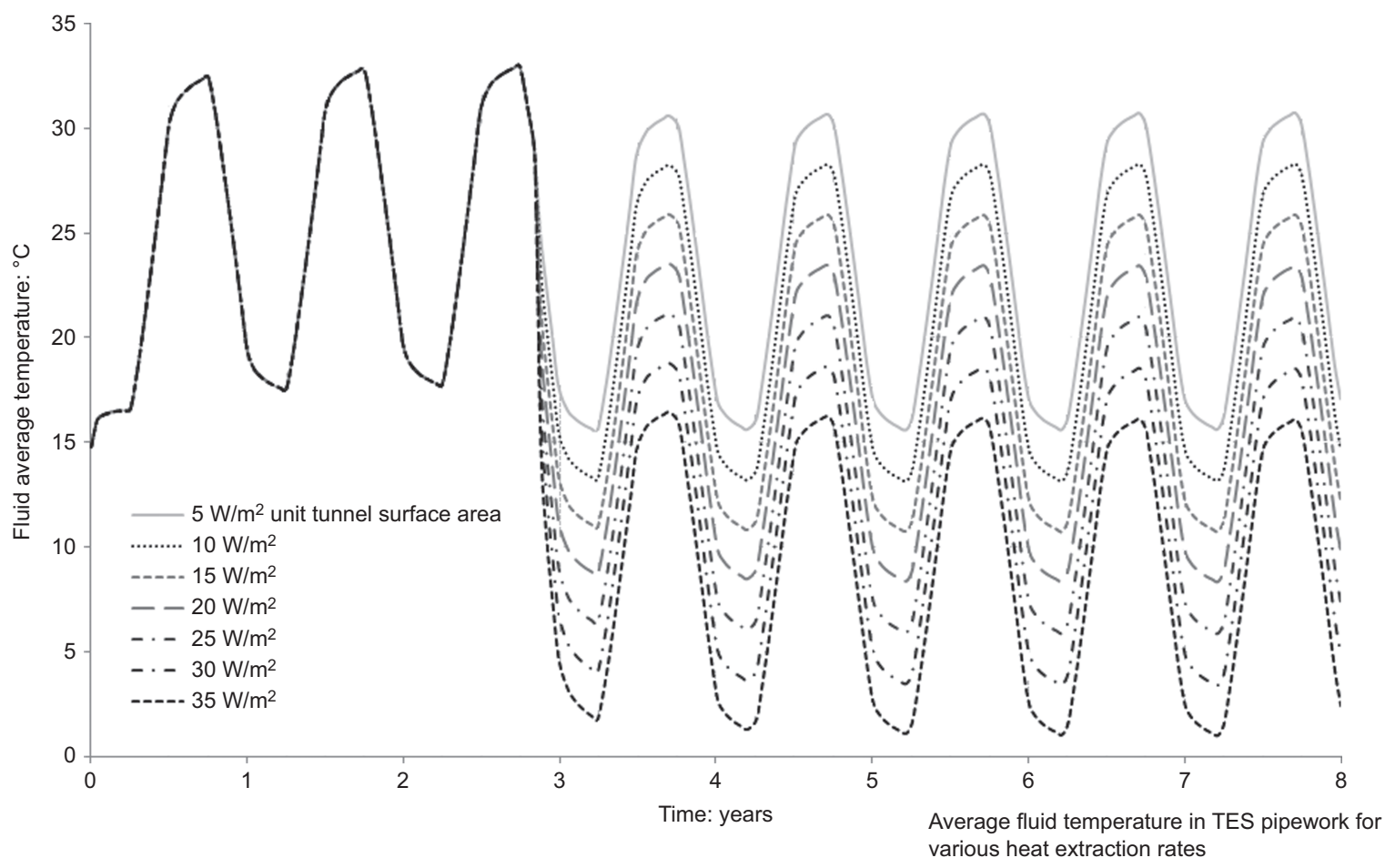

Figure 9. Predicted fluid temperature inside pipes over time for various extraction rates. No heat extraction within the first 3 years

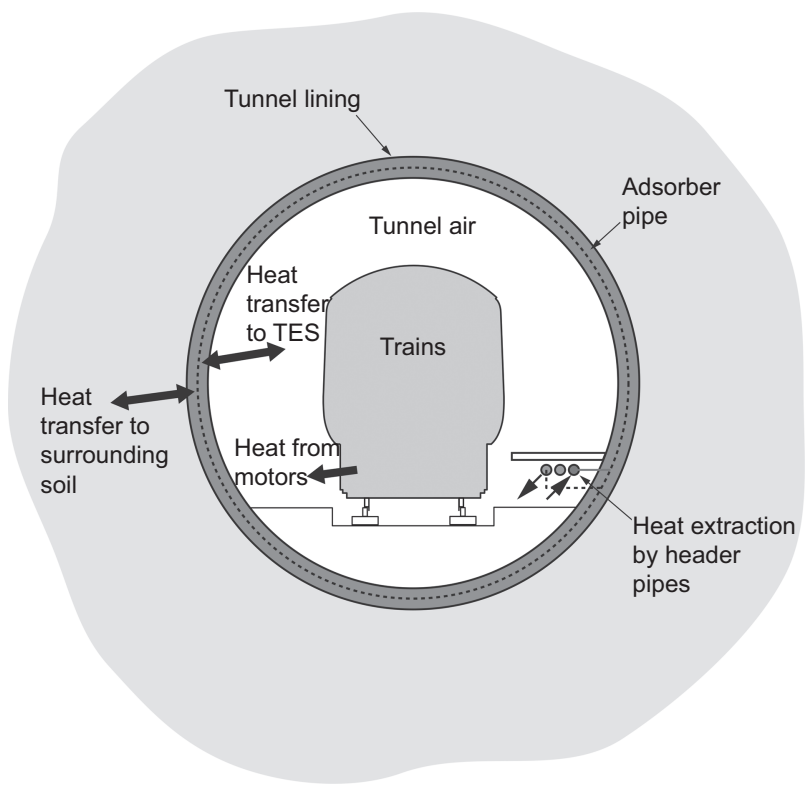

Figure 10. The ventilation model set-up, showing heat transfer from air to tunnel and surrounding soil reductions were achieved in areas such as tunnels east of Stepney Green junction; this was mainly attributable to the lower tunnel temperature within this section.

Most of the greater heat emission activities by the trains braking, acceleration and long residence times - happen close to the stations. One alternative design to improve the efficiency of the system is to install the TES pipework only in the close proximity of the stations. The peak tunnel air temperature in these areas is predicted to drop by up to $4^{\circ} \mathrm{C} \mathrm{DB}$ at $20 \mathrm{~W} / \mathrm{m}^{2}$ heat extraction rate.

It should be noted that whenever the train heat inputs to the tunnels are lower than this full service pattern (for example in the early years of operation), a lower heat extraction rate would be required to keep the circulation fluid temperatures above freezing. Lower inlet temperature would have an impact on output from the heat pumps.

When the Crossrail is in operation, the bored tunnels are expected to be warmer than the surrounding ground due to heat emitted by the trains. Under the current design some of the heat is removed by air exchange through the draught relief ducts, and some dissipates through the tunnel walls to 


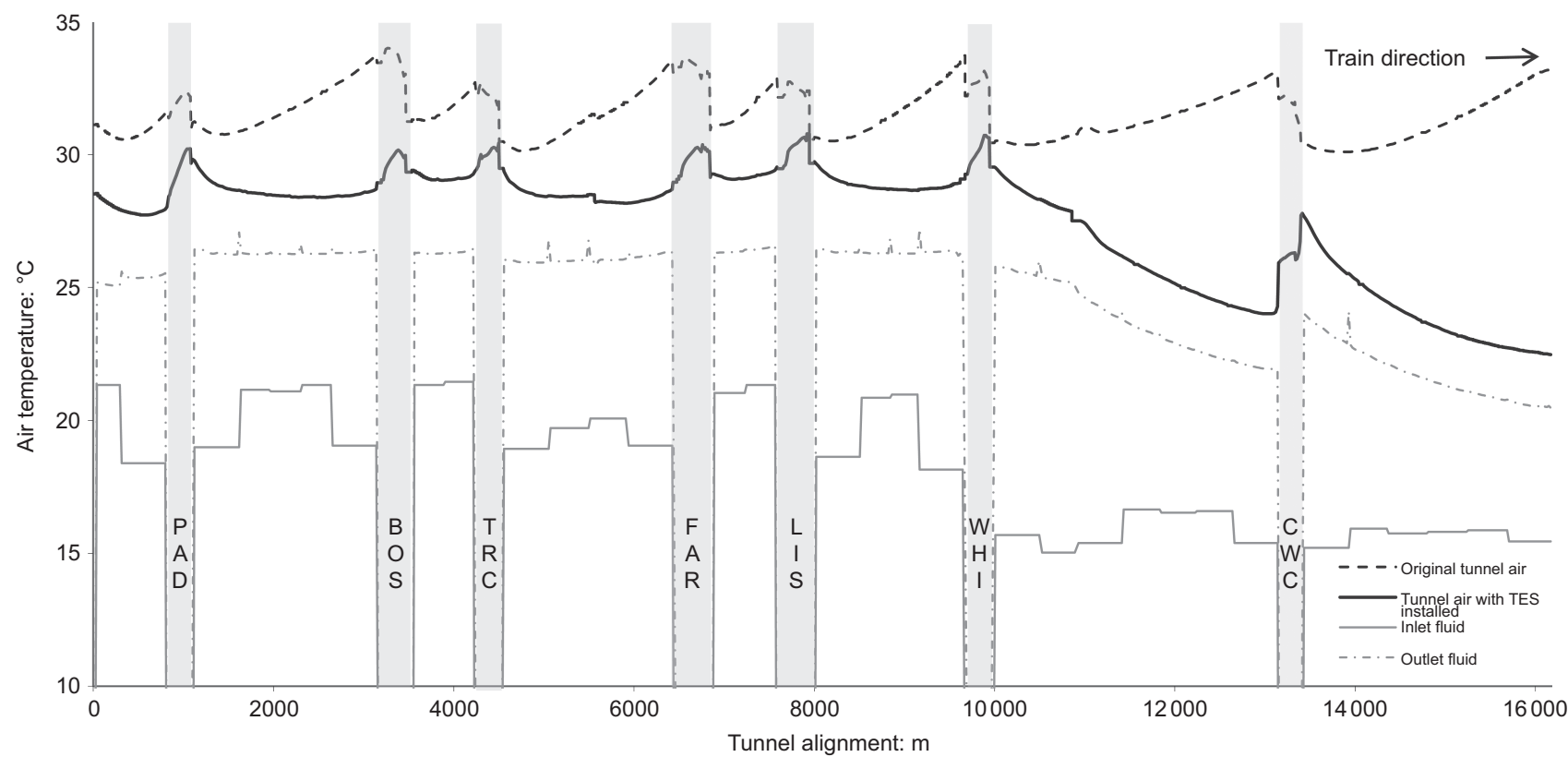

Figure 11. Predicted tunnel air temperature along eastbound route from Royal Oak portal to Canary Wharf Victoria Dock portal during summer peak hours, with full installation along the running tunnel and a fixed heat extraction rate of $10 \mathrm{~W} / \mathrm{m}^{2}$. The inlet and outlet fluid temperatures are also shown

surrounding strata by thermal conduction. TES will offer significant benefits as it will prevent heat build-up in the ground, and reduce the tunnel air temperature. This will lead to savings in the tunnel ventilation system operational cost and

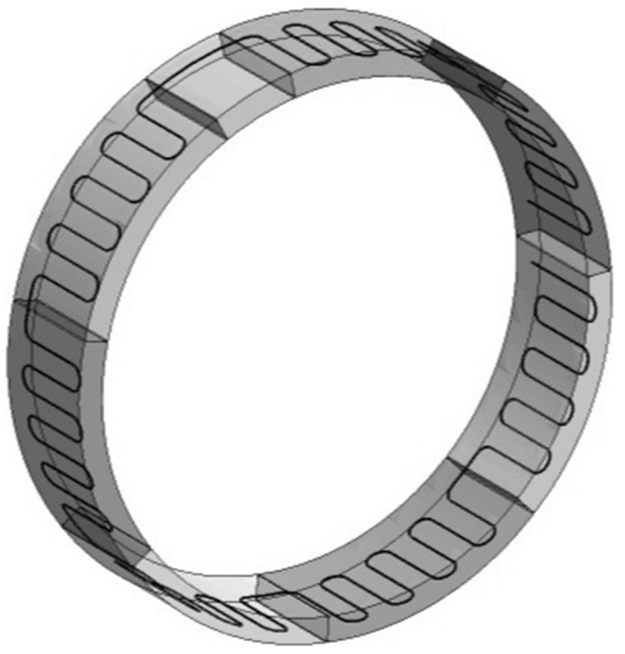

Figure 12. Set-up of the thermal-mechanical FE model for the Crossrail TES in LS-Dyna future proof the tunnel design for an increase in temperature due to climate change or higher train frequencies.

\section{Durability and operational considerations}

\subsection{Pipe durability}

The PE-Xa grade pipe, comprising high-pressure cross-linked polyethylene, or equivalent, has been specified because

tight pipe bending radii can be achieved

- it has robustness against notches, scratches and puncture loads during segment production and installation

a it allows for segment joint extension at the box-outs

a permanent mechanical connections can be formed

its durability requirements are in line with the tunnel design life (e.g. 120 years) at the pipe operating pressure and temperatures in accordance with DIN 16892 (DIN, 2000).

\subsection{Thermal effects on tunnel structure}

In order to understand the thermal effect on the tunnel structure, a three-dimensional FE model was developed using LS-Dyna to represent a tunnel with a typical soil profile. The tunnel element in the model comprises a $6.2 \mathrm{~m}$ dia. $300 \mathrm{~mm}$ thick concrete ring made of seven segments and a keystone; see Figure 12. The model is a coupled thermal-mechanical model. 


\begin{tabular}{ll} 
Strain & G/Gmax \\
\hline $3.04 \times 10^{-5}$ & 0.92 \\
$6.09 \times 10^{-5}$ & 0.75 \\
0.000101 & 0.53 \\
0.000121 & 0.29 \\
0.000820 & $0 \cdot 13$ \\
0.00171 & 0.075 \\
0.00352 & 0.044 \\
0.00969 & 0.017 \\
0.02223 & 0.0035 \\
0.0646 & 0 \\
$\lambda=0.1, \kappa=0.02,1=0.0019, \beta G=4, \beta_{\varnothing}=3, G_{\mathrm{vh}} / G_{\mathrm{hh}}=$ \\
$0.5, \mu=1.3$
\end{tabular}

Table 4. Brick parameters for London Clay

The assumed stratigraphy and the material properties used in the model are summarised in Table 3. Within the model, the made ground and the river terrace deposits were modelled using the elastic Mohr-Coulomb model, these formations were considered drained at all stages during the analysis. The London Clay and the Lambeth Group were modelled using the constitutive model Brick available in LS-Dyna. These clay-type materials were assumed to behave in an undrained manner. The inputs for Brick model are listed in Table 4. The concrete is modelled as a linear elastic material; the joint between segments is of a $3.5 \mathrm{~m}$ radius convex. Special interface elements are used to model the segment joint to allow rotational movement between the segments. The thermal properties used in the model are given in Table 2. The thermal expansion coefficient of the soil skeleton and the pore water was assumed to be $3 \cdot 0 \times 10^{-5} / \mathrm{K}$.

The coupled thermal-mechanical analyses were carried out for heat extraction rates from 0 (no heat extraction) to $30 \mathrm{~W} / \mathrm{m}^{2}$. Under natural conditions (i.e. no heat extraction), the warmed air in the tunnel causes it to expand, and the maximum computed tunnel movement is $1.1 \mathrm{~mm}$ expansion outward in the summer and $1.6 \mathrm{~mm}$ in the winter. There is negligible deformation at the crown and invert of the tunnel. Heat extraction reduces these displacements. At an extraction rate of $30 \mathrm{~W} / \mathrm{m}^{2}$ the tunnel shrinks at the axis level and expands at the crown during summer, and shrinks towards the centre during winter. The changes in tunnel diameter are summarised in Table 5. It is concluded that the $30 \mathrm{~W} / \mathrm{m}^{2}$ heat extraction would result in a further $1 \mathrm{~mm}$ deformation compared to the case of no heat extraction.

Hoop stress in the tunnel lining without thermal effects is predicted to be $4 \mathrm{MPa}$ at the crown depth of $16 \mathrm{~m}$. Handcalculated hoop stress in the tunnel lining, assuming the soil 
Nicholson, Chen, de Silva, Winter and Winterling

Tunnel diameter change: $\mathrm{mm}$

\begin{tabular}{lcr}
\cline { 2 - 3 } Simulation stage & Crown-invert & Axis leve \\
\hline Summer (no extraction) & $+0 \cdot 1$ & $-1 \cdot 1$ \\
Winter (no extraction) & -0.5 & $-1 \cdot 6$ \\
Summer (30 W/m ${ }^{2}$ heat extraction) & $+0 \cdot 3$ & -1.9 \\
Winter (30 W/m $\mathrm{m}^{2}$ heat extraction) & -0.6 & $-2 \cdot 6$
\end{tabular}

Table 5. Thermal effect on tunnel dimensions

density of $20 \mathrm{kN} / \mathrm{m}^{3}$, is approximately the same. As expected, the maximum hoop stress occurs at the convex to convex segmental joints. When no heat is extracted, the hoop stress (average through the segment thickness) shows a seasonal variation, being maximum in summer when it is $7 \%$ greater than the as-constructed condition. This rises by a further $2 \%$ when $30 \mathrm{~W} / \mathrm{m}^{2}$ heat extraction takes place. In winter, the average hoop stress is negligibly different from the asconstructed condition, whether heat is extracted or not. Although the heat extraction induces a relatively large temperature gradient across the thickness of the segments,
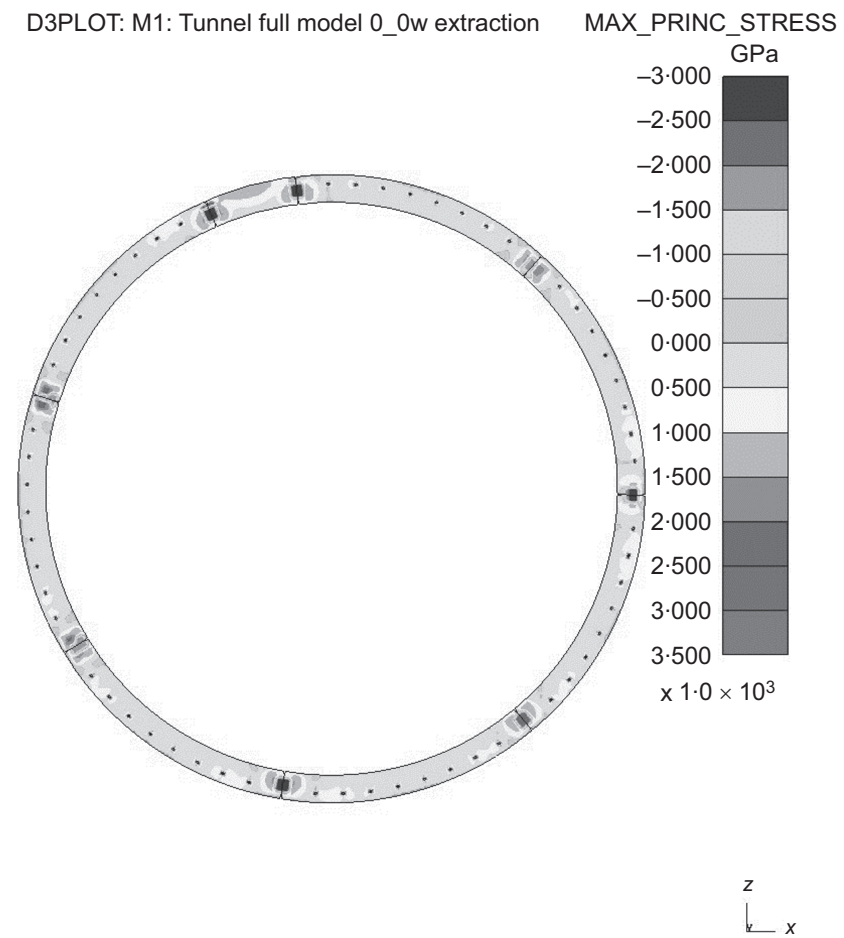

D3PLOT: M2: Tunnel full model 30_30

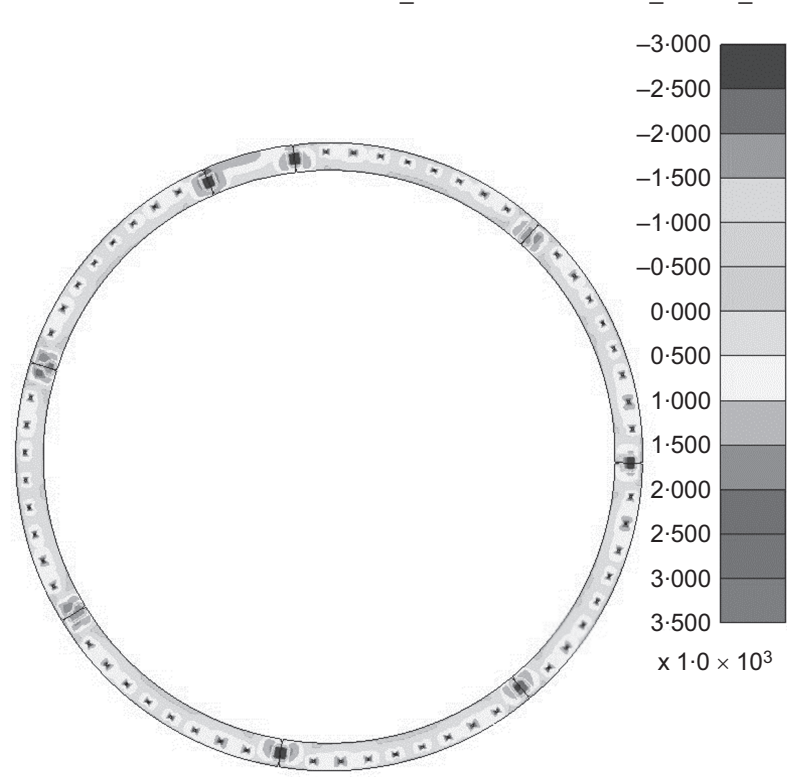

The computed tensile stress for no heat extraction and $30 \mathrm{~W} / \mathrm{m}^{2}$ during summer and winter is shown in Figure 13. For the ground conditions and geometry adopted in the analysis, the computed maximum tensile (bursting) stress occurs at the convex to convex joints. It is likely that the tensile bursting stress will be proportional to the contact force at the joints, which in turn is proportional to the average hoop stress. Therefore it is assumed that the bursting stress will rise the hoop stresses at both surfaces are predicted to remain compressive.
$-1 \cdot 1$

$-1 \cdot 9$

$-2 \cdot 6$ 
Engineering Sustainability

Volume 167 Issue ES3
The design of thermal tunnel energy segments for Crossrail, UK

Nicholson, Chen, de Silva, Winter and Winterling by $7 \%$ compared to the condition of no heat extraction, and by a further $2 \%$ if $30 \mathrm{~W} / \mathrm{m}^{2}$ is extracted.

Tensile stress is also expected around the embedded pipes when heat is extracted: it reaches a maximum of $3.5 \mathrm{MPa}$ when $30 \mathrm{~W} / \mathrm{m}^{2}$ is extracted. The resulting tensile stress is below the design tensile stress limit of 5.0 MPa.

\subsection{Fire safety}

The piping is made of $\mathrm{PE}-\mathrm{Xa}$, which is a form of polymer comprising molecular chains made up of hydrogen and carbon atoms. Through the cross-linking process, additional links are built between neighouring carbon atoms. The Crossrail fire safety strategy for the central tunnels (Crossrail, 2009) states that materials within the tunnels should be chosen based on the London Underground standard 1-085 fire safety performance of materials (London Underground, 2011). Section 5.6.1 of the Crossrail tunnel fire Safety strategy states that

Any materials which do not comply with this standard will be riskassessed to determine whether they are acceptable.

The London Underground standard 1-085 has fire safety requirements for materials with regard to flammability, smoke emission and toxic fume emission. The proposed TES inclusion of exposed cross-linked polyethylene pipe with the tunnel is not fully compliant with the standard in relation to flammability and potentially smoke emission. The Crossrail fire safety strategy for the central tunnels allows a risk assessment to be carried out in lieu of strict compliance with the 1-085 standard.

The embedded absorber piping is connected to a set of three header pipes, which are made of PE-Xa and are $90 \mathrm{~mm}$ in diameter. To mitigate fire risk the design is based on burying the header pipes in mass concrete.

\section{Operational and commercial benefits}

It is important to assess the fundamental financial viability of the TES system. The elements to consider with respect to costs are initial capital tunnelling cost, surface connection cost, cost incurred to connect the system to buildings and operational cost.

The benefits that TES brings to the tunnel operators are outlined below.

\subsection{Operational cost saving}

Excess heat can cause operational difficulties. For example, metro tunnels may see a large heat input from trains, whereas power cables may raise the internal temperature of service tunnels. Therefore, tunnel cooling often needs to be provided. The most cost-effective solution to achieve cooling would be natural ventilation; however, this is rarely sufficient and conventionally fans are used to provide forced ventilation.
Cooling the tunnel by means of the TES system will lead to savings in the operational cost of the ventilation fans. The heat capacity of the fluid in the absorber pipes embedded in the tunnel segments is much larger than air and hence allows for more efficient cooling than forced ventilation.

\subsection{Capital cost saving}

The physical size of the heat pumps may be significantly smaller than the air ventilation fans and associated air ducts that would normally be required for cooling the tunnel, hence allowing a more compact design and resulting in capital cost savings.

In some instances, using TES instead of forced air ventilation may even allow the tunnel diameter to be reduced, where it is governed by the required air flow area. In a similar way, intermediate ventilation shafts may be downsized or removed because of the reduced air flow. In the future if these opportunities are exploited, significant capital cost savings may be achieved. At Crossrail the TES design options could not be developed fast enough to enable reduction in air ventilation and under platform exhaust (UPE) usage to be incorporated into the design.

\subsection{Carbon saving}

The provision of heat energy to buildings adjacent to tunnels reduces their heat requirement - for example, the need for those buildings to heat air or water using conventional sources (gas, electricity, heating oil). On new construction work, the TES heat could be used at the planning stage as part of the renewable heat incentive or the part $\mathrm{L}$ renewable heating component. Accordingly, the use of TES provides a reduction in carbon output for the building being supplied with this heat energy. For example, $10 \mathrm{~W} / \mathrm{m}^{2}$ tunnel heat extraction provides enough heat to supply a continuous summer low temperature demand of $250 \mathrm{~kW}$, and approximately $170 \mathrm{~m}^{3} / \mathrm{d}$ domestic hot water load preheat (approximately equivalent to a 500-bed luxury hotel), achieving carbon savings of about $42 \%$.

\subsection{Heat revenue}

Selling the heat harvested from the tunnels to nearby properties will generate some direct income. In addition, income may be possible through the renewable heat incentive and/or the selling of carbon offsets.

With energy prices rising and supply uncertainty, the TES may offer an alternative solution. Compared with geothermal piles and vertical borehole loops, the unit energy price is lower for TES systems.

\section{Case study: Fisher Street to Tottenham Court Road}

A case study design of a $860 \mathrm{~m}$ long demonstration TES tunnel between Tottenham Court Road station and Fisher Street 


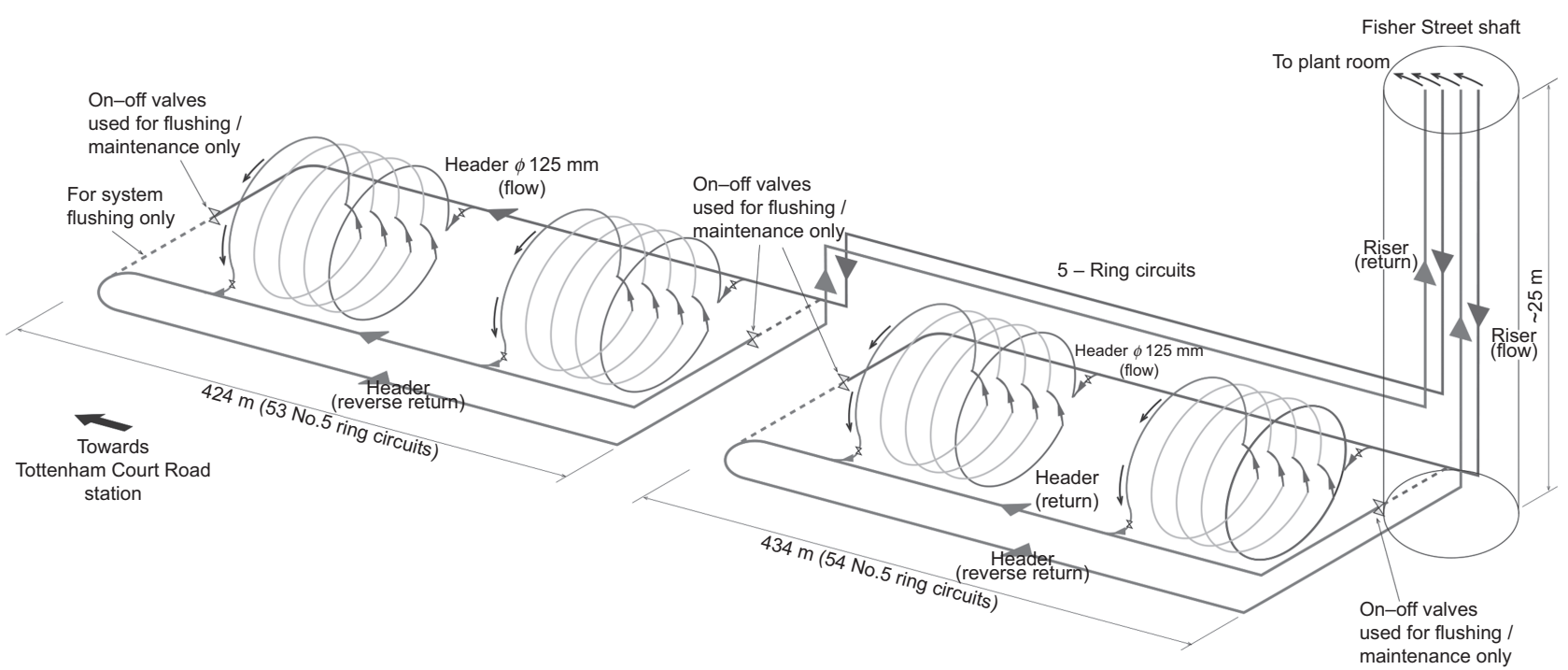

Figure 14. Sketch of the demonstration section design

shaft was developed for construction to show that all the technical issues could be addressed and costs could be quantified. In order to make full use of the tunnel length available the chosen tunnel was divided into two sections of about $430 \mathrm{~m}$, with two sets of header pipes coming in and out of the Fisher Street shaft, as shown in Figure 14.

The pressure drop at the maximum extraction rate of $30 \mathrm{~W} / \mathrm{m}^{2}$ is calculated as 7.5 bar during normal operation, and 10.3 bar during flushing. The effect of the locally installed TES on the tunnel temperatures is illustrated in Figure 15. Owing to the space limitations the plant room layout was modified to fit to an area of $4 \mathrm{~m}$ by $10 \mathrm{~m}$. The plant room is to accommodate the primary circuit - that is, circulation and standby pumps and the secondary and tertiary circuits are located at the end-user's premises.

In order to reduce the fire load, the headers are re-designed to be buried in mass concrete beneath the evacuation walkway. As a result, the fire load introduced by the TES over a $20 \mathrm{~m}$ length of tunnel duration $15 \mathrm{~min}$ is reduced to $375 \mathrm{~kW}$, and this is $4.2 \%$ of the designed train fire load of $8.8 \mathrm{MW}$ over a $20 \mathrm{~m}$ long carriage. Pure polyethylene complies with the London Underground material requirements in relation to toxic fume emissions.

The instrumentation and monitoring specifications were also developed both inside the tunnel and the plant room. The cost of the TES is relatively low compared to the tunnel construction budget. Excluding the one-off equipment modification cost, the manufacture and installation TES would cost between $£ 400$ and $£ 530$ per metre run of tunnel. Compared to conventional closed-loop ground source energy boreholes, the TES is more cost effective.

The following technical issues have been addressed for the development of the demonstrator TES section

an assessment of the local heat available from the trains and the soil

the development of the demonstrator section ventilation model that included TES

the TES and header pipe layouts to extract heat at Fisher Street shaft

the pipe layouts for the steel cage reinforced segments for the floating track slabs

the connection details between segments and rings and header pipes

- the space proofing and plant room arrangements

- the stress analysis for the thermal effects on tunnel linings

the assessment of fire risks

the construction processes for the segment moulds and their tunnel erection

the assessment of surface buildings within $100 \mathrm{~m}$ from the Crossrail route for heat use

the development of drawings, specifications, quantities and budget costs.

\section{Summary and conclusion}

This paper provides an overview of a TES system for Crossrail where heat is generated by the trains in the tunnels all year round. The system uses an embedded closed-loop water-filled 


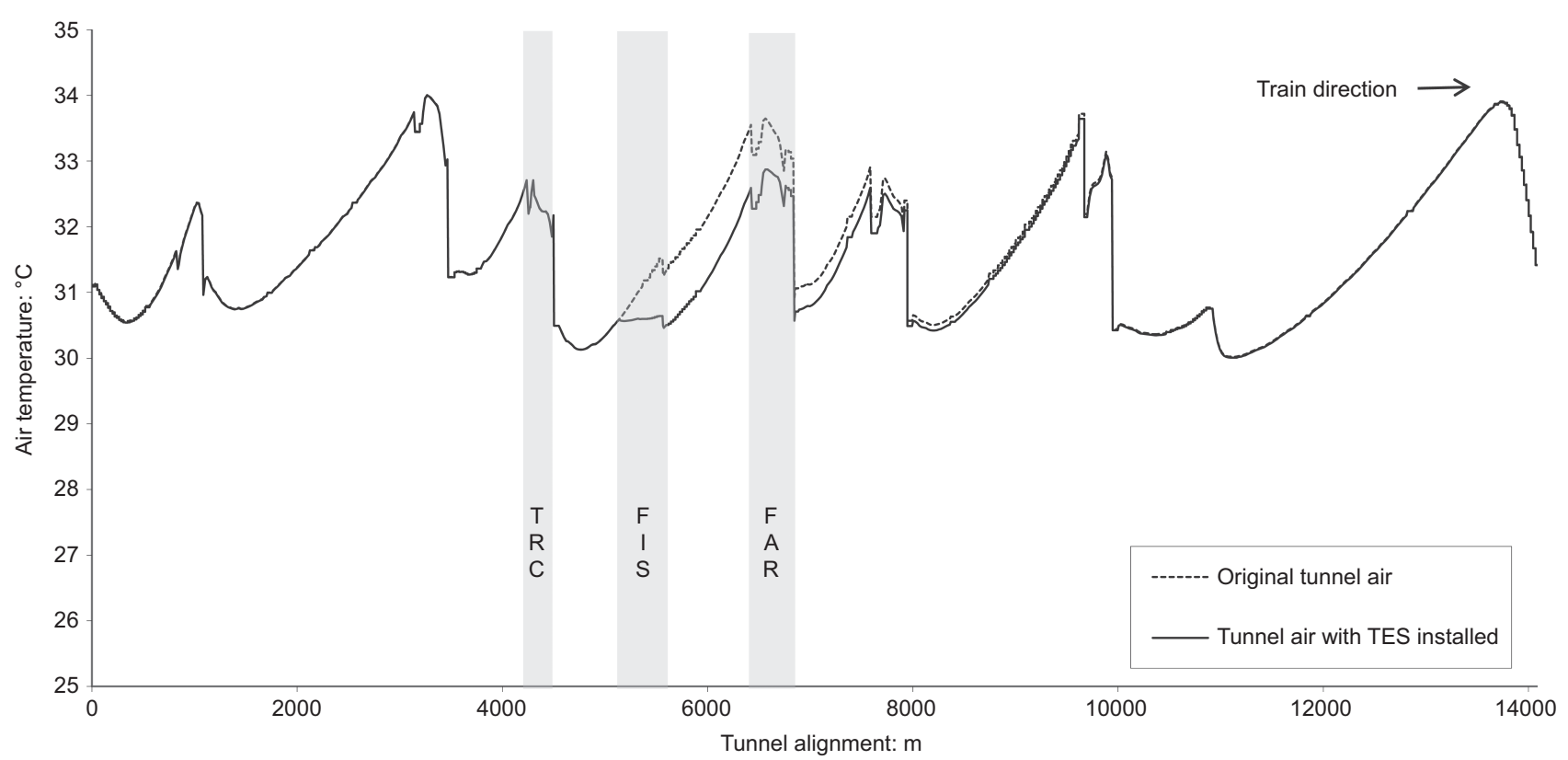

Figure 15. Predicted tunnel air temperature along westbound route from Pudding Mill Lane portal to Royal Oak portal during summer peak hours, with TES only installed between Fisher Street shaft and Tottenham Court Road and a fixed heat extraction rate of $10 \mathrm{~W} / \mathrm{m}^{2}$

pipework in tunnel segments to extract this heat. In this way it both cools the tunnels and provides heat for adjacent buildings. The water temperature supplied to the heat pumps is relatively high, enabling the system to operate at a higher COP compared with conventional ground source heating systems.

A major challenge for the TES project was the coordination of the multidisciplinary team to deliver the design and costing studies for the TES project.

The TES is a viable technology for the future 'smart' cooling of tunnels; 'smart' because it extracts heat in a form that can be utilised and with a potential revenue stream and because it can be used to reduce the reliance on UPE and tunnel ventilation systems, thus saving on electrical energy. These two benefits provide significant carbon and financial savings at a time when there is a focus on carbon reduction and when fuel costs are anticipated to increase between $50 \sim 100 \%$ decade on decade in real terms. The project did not go ahead because of time constraints and high mould modification costs. Nevertheless, the development of this technology on Crossrail has provided a vital building block in understanding the benefits of the system such that it can be implemented at scale on future projects.
It is considered that the technical and commercial problems associated with the TES have been sufficiently addressed to warrant a demonstration tunnel to prove the system for use in future tunnels. Thinking one step ahead to future proofing during new metro design and construction is important.

The project received the 2011 'Technical Innovation of the Year' by International Tunnelling Awards and the 2011 'Innovative use of Equipment' by Tunnels \& Tunnelling International Awards.

\section{Acknowledgements}

The authors would like to thank all who were involved in this project, in particular Anton Pillai, David Eckford, David Whitaker, Eren Musluoglu, Mohammad Tabarra, Richard Strut and Steve Doran. The authors are also grateful to Duncan Wilikson and Rob McCrae for their insightful guidance and support. This work is funded by C Ltd.

\section{REFERENCES}

Adam D and Markiewicz R (2009) Energy from earth-coupled structures, foundations, tunnels and sewers. Géotechnique 59(3): 229-236.

Biotto C, Eckford D and Chen Q (2013) Efficient tunnel cooling using tunnel wall heat extraction. Proceedings of the 15th 
The design of thermal tunnel energy segments for Crossrail, UK

Nicholson, Chen, de Silva, Winter and Winterling
International Symposium on Aerodynamics, Ventilation \& Fire in Tunnels, Barcelona, Spain.

Botelle M, Payne K and Redhead B (2010) Squeezing the heat out of London's Tube. Proceedings of the Institution of Civil Engineers - Civil Engineering 163(3): 114-122.

Brandl H (2006) Energy foundation and other thermo-active ground structures. Géotechnique 56(2): 81-122.

Brandl $\mathrm{H}$, Adam D, Markiewicz R, Utenberger $\mathrm{W}$ and Hofinger $\mathrm{H}$ (2010) Massivabsorbertechnologie zur Erdwarmenutzung bei der Wiener U-Bahnlinie U2, Osterr. Ingenieur-und Architekten-Zeitschrift 155(7-9) and (10-12): 1-7.

CIBSE (Chartered Institution of Building Services Engineers) (2007) Guide C: Reference Data. CIBSE, London, UK.

Crossrail (2009) Fire Safety Strategy for the Central Tunnels, C124-MMD-08-TPL-CR001-0006, rev1. Crossrail, London, UK.

Defra (Department for Environment, Food and Rural Affairs) (2011) Climate Resilient Infrastructure: Preparing for a Changing Climate. Defra, London, UK. Presented to parliament, Cm8065, May 2011.

Defra (2012) The UK Climate Change Risk Assessment 2012
Evidence Report. Defra, London, UK. Presented to parliament pursuant to Section 56 of the Climate Change Act 2008.

DIN (Deutsches Institut für Normung) (2000) DIN 16892: Crosslinked polyethylene (PE-X) pipes - general requirements, testing. DIN, Berlin, Germany.

Franzius JN and Pralle N (2011) Turning segmental tunnels into sources of renewable energy. Proceedings of the Institution of Civil Engineers - Civil Engineering 164: 35-40.

Fry VA (2009) Lessons from London: regulation of open-loop ground source heat pumps in central London. Quarterly Journal of Engineering Geology and Hydrogeology 42(3): 325-334.

London Underground (2011) Fire Safety Performance of Materials, 1-085, Issue A3. London Underground, London, UK.

MIS (2013) MIS 3005: Heat pump standard. See http://www. microgenerationcertification.org/mcs-standards/installerstandards (accessed 26/04/2014).

Schneider M and Moormann C (2010) GeoTU6 - a geothermal research project for tunnels. Tunnel 02/2010: 14-21.

\section{WHAT DO YOU THINK?}

To discuss this paper, please email up to 500 words to the editor at journals@ice.org.uk. Your contribution will be forwarded to the author(s) for a reply and, if considered appropriate by the editorial panel, will be published as discussion in a future issue of the journal.

Proceedings journals rely entirely on contributions sent in by civil engineering professionals, academics and students. Papers should be 2000-5000 words long (briefing papers should be 1000-2000 words long), with adequate illustrations and references. You can submit your paper online via www.icevirtuallibrary.com/content/journals, where you will also find detailed author guidelines. 